\title{
The South African Digital Access Index
}

\section{Zandi Lesame}

\section{Doi:10.5901/mjss.2014.v5n10p331}

\author{
University of South Africa, Email: lesamnc@unisa.ac.za
}

\begin{abstract}
International and national data made available during the past few years indicate that access to and use of information and communication technology (ICT) and services is experiencing slow growth in South Africa. In the early 2000s, South Africa led Africa in terms of ICT infrastructure development. However, more recent ICT statistics indicate that other African countries, such as Nigeria and Mauritius are advancing faster than South Africa in this regard. The World Economic Forum Global Information and Communication Report (2012, in e-Skills Institute Newsletter, 2012a) states that the sub-Saharan African region still has the least developed ICT infrastructure in the world, and also has a severe lack of ICT skills. Having considered the Southern African ICT infrastructure deficiencies, this article captures and evaluates ICT policy and regulatory interventions instituted by South Africa towards the creation of a knowledge society. The article starts by providing brief historical background on ICT access and use in South Africa, and states the stakeholders engaged in transforming South Africa towards e-readiness. The Digital Access Index is applied as a measuring instrument or research method to measure the South African e-readiness status. Further, the article evaluates the progress of South Africa towards becoming an information society by comparing levels of public access to, and usage of ICT in South Africa with those of selected African countries and BRICS (Brazil, Russia, India, China and South Africa) countries.
\end{abstract}

Keywords: Digital inclusion; digital literacy; digital access index, information society; technology access; e-skills; internet economy; information superhighway or Internet

\section{Introduction}

Historically, South Africa has been characterized by development and information production and use imbalances that were mostly associated with the digital divide in the country (Oyedemi, 2011). The advent of democracy in 1994 changed the apartheid legacy on information production and usage by working towards providing information and communication technology (ICT) to most citizens by creating laws and policies geared toward achieving universal access to ICT and digital inclusion (Lesame, 2009). One of the legal documents promulgating access to technology and information by citizens is the South African Constitution, according to which, "Everyone has the right of access to any information that is held by state or another person and that is required for the executive protection of rights" (Ch. 2, sec. 32 of the Bill of Rights in the South African Constitution 1996). Much literature and documentation has been recorded on the digital divide in South Africa (Horwitz \& Currie, 2007; Fuchs \& Horak, 2008). Furthermore, South Africa's vision of the information society is enshrined in Presidential and Ministerial speeches on the information society policy (Mandela, 1995; Mbeki, 2003; Matsepe-Casaburri, 2005; Padayachie, 2010).

South Africa has made some progress towards becoming a network and information society. However, much still has to be done for South Africa to reach that development status. Local telecommunications policy and sector analysts and ICT policy-makers have, over the past few years, expressed concern in the media about the slow improvement of the ICT infrastructure towards achieving universal access to ICT, which has a negative impact on progress to the development of an information society and the reduction of high illiteracy levels. This article chronicles the development of an information society in South Africa by providing an analysis of key ICT indicators that form the basis of an information society with the purpose of understanding whether or not these ICT statistics to create ubiquity in ICT access and use. The article features the Digital Access Index (DAI), as a research method, developed by the International Telecommunication Union (ITU) as an information-society measuring and benchmarking tool. The DAI employs indicators based around five categories, to measure countries' ICT development. The index is used to measure access to ICT in terms of infrastructure, affordability, knowledge (or literacy levels), quality and actual usage of technology (Padayachie, 2010). Secondary data are provided as collected from other national surveys on ICT data, namely the Statistics South African Census (2011) and the South African Network Survey (2013).

In the final analysis, this article contributes input to the Southern African digital divide and universal access ICT policy debates, and records the historical development of South Africa as an information society since 1996, when the 
first Telecommunications Act No. 103 was enacted by the democratic government, while there had been absence of such a legal framework in this regard for many years during apartheid. This history can better inform present ICT policy makers about which ICT services require their attention and development, as well as future industry policy directives and the implementation thereof. International views on the status of South Africa as an information society are also critical. Such views alert national ICT policy makers about ICT that needs rapid development for the benefit of the public. In this regard, the 2012 World Economic Forum (WEF) "Networked Readiness" Report of 142 countries states that despite being one of the most solid political and regulatory environments $\left(23^{\text {rd }}\right)$, and better framework conditions for entrepreneurs and innovation $\left(50^{\text {th }}\right)$ in the sub-Saharan African region, South Africa occupied $72^{\text {nd }}$ place and is not yet leveraging the potential benefits associated with ICT (e-Skills Newsletter, 2012a).

The fact that South Africa is no longer the African leader in ICT infrastructure and access, especially Internet access, when compared to countries such as Nigeria, (as depicted in Table 1), has also caused more concern regarding South Africa's stagnant status as an information society, because South Africa still remains the African economic leader.

Table 1: Percentage of Internet-connected South Africans compared to those of selected African countries

\begin{tabular}{|l|c|l|c|}
\hline African country & Percentage of people connected to the Internet & \multicolumn{1}{|c|}{ 2012 Ranking } & Ranking by growth rate (2008 to 2012) \\
\hline Botswana & 29 & 2 - Upper middle income & 1 \\
\hline Cameroon & 14 & 5 - Lower middle income & 2 \\
\hline Ethiopia & 3 & 10 - Low income & 8 \\
\hline Kenya & 26 & 3 - Low income & 7 \\
\hline Namibia & 16 & 4 - Upper middle income & 4 \\
\hline Rwanda & 6 & 8 - Low income & 6 \\
\hline South Africa & 34 & 1 - Upper middle income & 9 \\
\hline Tanzania & 4 & 9 - Low income & 3 \\
\hline Uganda & 8 & 7 - Low income & \\
\hline
\end{tabular}

Source: The South African Network Survey, in City Press (2013: 25)

Table 1 indicates that Botswana's Internet growth over the stated years was the fastest of the nine countries surveyed, followed by Ethiopia's, which interestingly enough is a low income country which has managed to fast-track its Internet development better than upper middle income countries such as Namibia and South Africa. Uganda and Rwanda are other low income countries which have fast Internet growth rates regardless of their economic status as low income countries. On the contrary, South Africa is Africa's economic powerhouse but rates sixth in terms on Internet growth rate in Africa.

The WEF Global IT Report (2013, in e-Skills Institute Newsletter, 2013) stated that South Africa had gone up two positions from $72^{\text {nd }}$ place in 2013 to $70^{\text {th }}$, in terms of ICT development when compared to other countries in the list of 142 countries. However, this cannot be interpreted as a real improvement, or actual improvement, when considering what this same report states next, that: "Despite a sharp improvement in the development of its ICT infrastructure (59th $)$ - notably in terms of international Internet bandwidth capacity $\left(66^{\text {th }}\right)$ - and a strong uptake by the business community $\left(33^{\text {rd }}\right)$, the ICT impacts $\left(92^{\text {nd }}\right)$, particularly the social ones $\left(112^{\text {th }}\right)$, remain limited". The perception of a lack of clear government vision $\left(105^{\text {th }}\right)$ to orchestrate and implement a holistic ICT strategy for the country, coupled with deficiencies in the educational system for some segments of the rather positive political and regulatory framework for ICT development ( $\left.55^{\text {th }}\right)$.

South African ICT data indicate limited access to and use of most technology except mobile phones. High mobile phone access and usage levels, however, have not reduced digital exclusion but improved universal access to communications technology to a limited extent. In its report (2011), the South African National Planning Commission (NPC), a body appointed by the South African government to assess development challenges and obstacles in the country, declared that "ICT and broadband networks are at the core of economic-recovery strategies". However, if these ICT networks are underdeveloped and continue to remain so, South Africa may not experience the economic recovery desired by the NPC and the government. Information summarized in this article indicates that the lack of development of ICT facilities in the country exacerbates the digital exclusion that continues to contribute to the creation of development barriers, rather than the creation of economic opportunities. Digital exclusion further contributes to the problem of digital illiteracy and a lack of much-needed e-skills. The ultimate goal of developing an information society is to empower individuals to be able to access the world of electronic information and utilize it (Padayachie, 2010). However, Padayachie (2010) also noted in that report, that South Africa is grappling with an ICT deployment challenge because the government has not yet succeeded in its attempts to deploy ICT widely, as planned in its policy documents, hence the government has sought the assistance of the private sector and other interested stakeholders towards achieving this goal. 
The next section of the article provides a brief history of the information society concept around the world and in South Africa. Section 3 of this article describes the research methodology employed to collect and analyze data while Section 4 provides the findings on ICT data available and used nationally. Other data reported are from the national ICT Survey from Statistics South Africa, conducted in 2011 (Statistics South Africa Census, 2011). Finally, the article ends with concluding remarks and recommendations on the topic under discussion.

\section{Meaning of and Background on the Global and National Information Society}

An information society is defined as a society that is able to transform itself by living, working, and playing through the exploitation of technology. This transformation is expected to bring both significant opportunities and tremendous challenges for governments, organizations, and individuals as ICT changes the way they live and arranges their lives around the use of technology, such as mobile phones and computers. The South African government defines the information society as "a society that provides ICT access to people so that they can utilize it to improve their work and lives" (Padayachie, 2010). This definition provides a quandary for South Africans because most people in South Africa have no access to ICT and are therefore unable to utilize it for work or to improve their lives. What most South Africans access and use are mobile phones, as later sections of this article show, but these mobile phones (as indicated by the 2012 and 2013 WEF Reports) have not improved their lives, although they have improved how people communicate with others - mainly voice communication and sending short message service (SMS). Access to and use of social media in on the rise as most people access these from mobile phones..

Shedding more light on the meaning of the information society, Lyotard (1984) affirmed that information has acquired a new place and value in contemporary society. In other words, an information society is a society in which the creation, distribution, use, and manipulation of information has become a significant economic, political, and cultural activity. Information is the central driving force society.

Different scholars approach the information society from national perspectives and interests. For example, some scholars consider the information society the result of technological determinism because of the spread of computers and ICT; while other writers consider the information society a cultural phenomenon, or even an imaginary product-a "social construction," produced in post-modern talk and rhetoric (Sussman, 1999). Other writers such as Castells (2000) consider the information society as one consisting of a configuration of complex networks of social relationships, mostly development around and within computer networks.

The Tunis phase of the World Summit on the Information Society (WSIS, 2005), is considered as the end of the industrial era and the beginning of the information age. This period in human history is characterized by the production, sharing, and use of information as a phenomenon that shapes human relations, business transactions, and government plans and operations. The WSIS Declaration of Principles (2005) stated that an information society is one in which "everyone can create, utilize and share information and knowledge, enabling individuals, communities and people to achieve their full potential in promoting sustainable development and improving the quality of life". Since the administration of former Presidents Nelson Mandela and Thabo Mbeki, the South African government developed regulatory frameworks geared towards promoting South Africa as an information society, which include the Telecommunications Act 103 of 1996, the Telecommunications Amendment Act 64 of 2001, the New Partnership for African Development (NEPAD) Terrestrial and Submarine (EASSy) Broadband project, which covers 23 countries in East and Southern Africa, the Information Society and Development (ISAD) Plan and Multi-Stakeholder Policy Formulating Body, which is based at the national Department of Communications (DoC), as well as the Broadband Policy of 2013 (Mungadze, 2013). These policies all promote access to ICT services but the ubiquity of ICT services has not yet happened. First democratic President, global icon and South African father of democracy, Nelson Mandela (1995, also in ICTD, 2013) affirmed that "it is imperative that the global ICT revolution creates a world-wide information society in which everyone has a stake and can play a part, then it will not have been a revolution at all". Nineteen years since President Mandela echoed those words, there is still a wide gap between the information rich and information-poor in South Africa as ICT indicators provided in the latter sections of this article indicate. South Africa also lacks the capacity, at policy development and practical ICT delivery levels, to bridge the digital access and information divides.

Addressing the WSIS in Tunisia in 2005, former President Mbeki promoted the creation of an information society by stating that the "creation and development-oriented information society is in the best interest of the majority of humanity because most of the peoples of the world, especially from developing countries, are confronted by the challenge of exclusion in the context of global economy, in whose development modern information and communications technologies play a vital role" (South African Presidential National Commission on Information and Development (PNC on ISAD): Towards an inclusive Information Society, 2005: 2). However, Mbeki's ICT Policy (2000 to 2007) failed to improve 
universal access to the ICT infrastructure and services.

From 2007 onwards, the South African government implemented several policy interventions and ICT projects to create a South African information society. Some of these interventions and projects are mentioned in this article. Most citizens do not have access to most ICT necessary to work, earn profits, and improve lives and do not enjoy the benefits gained from using ICT since most are unemployed and suffer from poverty and social deprivation. The unemployment rate in South Africa decreased from 24.5 per cent in the third quarter of 2013 to 24.1 per cent in the fourth quarter of 2013 (SA Unemployment Rate 2014). Joblessness, poverty and inequality are major national issues.

Former South African Minister of Communications, Pule (who was fired in 2013 by current President Zuma for nepotism, abuse of funds and power, as well as corruption - City Press 2013a; 2013b), recognized the social deprivation challenge of South Africans and declared, while opening an e-Skills Summit that "the historical imbalances between the advantaged and disadvantaged will be with us for quite some time and that it will take an even greater struggle, involving even greater commitment and passion, to create a more equal society in all aspects of our society and country" (Pule, 2010). Pule (2010) alluded to the challenge facing the Communications Ministry, which is to "narrow the gap between the haves and have-nots, the skilled and the unskilled, as well as bridge new gaps, particularly those created by the digital age". One of the strategies the Ministry of Communications adopted and implemented to address this challenge is the development of an e-skills policy (from 2009 onwards), located within the broader ICT policy, aimed at teaching young people e-skills to improve their chances of gaining employment in the public and private ICT sectors. The e-skills policy is aimed at addressing the lack of ICT skills. South Africa had a "major e-skills shortage is beyond doubt - with the communications industry alone requiring 70, 000 people" (Wesso, 2010, 1). What is also inherently evident, and has been adopted by the South African government as a strategy to address e-skills shortages and teach ICT skills in different ICT centres and organizations around the country, is that public-private partnerships (PPP) are the best way to bring together government and private sector resources to improve ICT skills and embark on extensive e-skills training programs. Universities and municipalities have also joined in the pursuit of ICT skills training to improve the numbers of people digitally literate and employable in the ICT sector. It is crucial to note that some Asian countries such as Malaysia started implementing PPP projects in ICT for development (ICT4D) programs as early as the year 2000 (Songan, Harris, Bala \& Khoo, 2000), so South Africa has implemented this development strategy later than other developing countries, especially Asian .

E-skills encompass all the ICT skills required to operate in the digital work environment, including working in ICT sub-sectors, such as e-government, e-health, and other work environments that demand ICT usage. Multi-stakeholder agreements are entered into, in meetings and conferences, the aim of which is ICT skills training and the creation of an inclusive information society. Most of the ICT centres deployed by government alone in the 1990s have not been sustained and most closed down; but since 2009 government embarked on partnerships with the private sector and educational institutions to ensure sustainability and success of the ICT centres and training programs. In 2005, the WSIS process stated that e-skills are essential in empowering individuals so that they can fully participate as citizens of the Information Society, and take advantage of all the opportunities presented to them: opportunities for employment and wealth creation, for taking advantage of innovative education and learning strategies, and for using new life-enhancing services, such as interaction with public authorities (NeSPA, 2010, 1).

The rollout of technology throughout the country by multi-stakeholders, both in the public and private sectors, is aimed at reducing this divide. Although the government and the private sector still have a long way to go towards eliminating the digital divide and digital exclusion, South Africa is taking small steps towards addressing these challenges. This paper assesses the policy interventions, and ICT projects that have been implemented in South Africa during the past few years towards creating an information society. Over the democracy years (specifically 1996 to 2013), South Africa has witnessed continuous but dawdling growth in ICT services and uptake. Fixed telephony continues to decline, while access to computers, the internet, and mobile phones continue to improve, as figures in later sections of this article indicate.

\section{Research Methodology}

One of the indices employed to measure the information society (IS) is the ITU'S DAI (Padayachie, 2010). The DAI-IS measuring score is used because most of the data encapsulated within this index are readily available and it is, therefore, possible to record this information and use it to analyze the status of South Africa as an information society in 2014. As a conceptual framework, the DAI is divided into five scores (Padayachie, 2010), which are the following sub-indices:

(a) Infrastructure score: This sub-index captures ICT readiness (e-readiness), and includes two infrastructure and access indicators, namely, fixed-telephony (the number of lines per 100 population) and mobile telephony (the number of subscribers per 100 inhabitants); 
(b) Knowledge score: This sub-index captures ICT intensity, and includes three ICT intensity and usage indicators, namely, percentage of adult literacy (those who can read and write aged over 15 years of age).

(c) Quality score: This sub-index measures the number of internet subscribers per 100 inhabitants (excluding dial up) and international internet bandwidth per inhabitant.

(d) Usage score - indicates the number of Internet subscribers per 100 inhabitants.

(e) Affordability score measures Internet usage per month), expressed as a percentage of per capita income, subtracted from per capita income.

Additional statistics included in this article were reported by and adopted from Statistics South Africa Census (2011) and the South African Network Society Survey (2013).

\section{The South African Information Society Statistics: Critical Data Analysis}

South Africa has a population of more than 52 million people (Statistics South Africa Census, 2011). It is home to six (6) per cent of Africa's population and produces 25 per cent of the continent's gross domestic product (GDP) (Kaisara \& Pather, 2011). Although South Africa is classified by the World Bank as a middle-income country, the post-apartheid democratic government inherited a society characterized by a huge range of developmental levels and, as such, it remains one of the world's most inequitable societies with extensive disparities between rich and poor (Oyedemi, 2011). Despite the government's well-intended policy reform and service delivery initiatives, economic and social disparities still perpetuate. Mda (2014) emphasizes that the rich versus poor inequality is as glaring in 2014 as it was in 2007, when former president Mbeki announced that South Africa is country with two economies - a developed economy serving the rich and an another undeveloped economy serving the poor. "Democracy has failed to level the economic playing field" (Mda 2014). While there have been some success (e.g. South Africa was ranked $44^{\text {th }}$ out of 131 countries in the World Economic Forum's Global Competitiveness Report 2007/8), there are a number of areas in which inequalities prevailthe chronic digital divide is one such area (Lesame, 2009; Chisango, 2013). The digital divide is a phenomenon linked not only to access to new technologies, such as computers and the internet, but also unequal access to and usage of new technologies (Fuchs \& Horak, 2008). The issue of inequality is connected to the topic of the digital divide because technology is one aspect of material wealth, and wealth production is more and more often based on technology and knowledge. In South Africa those without material wealth have no ICT access and use, and therefore no access to education and knowledge.

The discussion in the next section assesses how South African ICT services have developed as assessed with the DAl sub-indices mentioned in the previous section.

\subsection{Infrastructure, Knowledge and Affordability Scores}

The South African ICT Development Index (IDI) dropped 10 places from 2002 to 2007 (ITU, 2011). South Africa, the largest African economy and the top economy in Sub-Saharan Africa, ranked 87th in ITU's IDI ranking in 2007 (and 77th in 2002). According to the ITU (2011), and the South African Ministry of Communications (Bapela, 2011), national ICT statistics that were measured by means of the E-Barometer ICT Index indicated that the country has relatively low ICT access and usage values, and little progress was made in improving ICT access and use between 2002 and 2007. For example, international internet bandwidth was only 852 bits/s/user in 2011 (similar to that in Ethiopia when compared to that in Tunisia, which was 1800 bits/s/user) (ITU, 2011). Tunisia, unlike South Africa, moved up the ICT Development Index (IDI) since 2002, and in 2007 moved up 11 places in IDI ranking to become number 83 in the world. This improvement is due to both improved ICT access and skills in that country. For example, mobile cellular telephone penetration was 76 per cent in 2007, up from six per cent in 2002, and tertiary enrolment increased from 23 per cent in 2002 to 32 per cent in 2007 (ITU, 2011). Bapela (2011) indicates that the South African e-Barometer Index revealed that the ICT sector group of indicators indicated an average growth of -1.43 per cent for the period from 2006 to 2009 while on the other hand, the Compound Annual Growth Rate (CAGR) for the education group of indicators demonstrated a low at 0.96 per cent for the same period. The education sector's adoption of ICT, which plays a significant role in improving the quality of education when those being educated have access to and can effectively use ICT, ensuring accessibility of information and knowledge.

\subsubsection{Fixed-line penetration, mobile phone access and access to television and radio services}

South African Ministers and Deputy Ministers of Communications, as well as industry analysts, often state that fixed-line 
penetration has been dropping in South Africa since the early 2000s (Pule, 2010; Perry, 2011; Goldstuck, 2012). A core reason for low penetration in South Africa is price - the affordability score (World Wide Worx, 2012). The telecommunications incumbent operator, Telkom, has failed to lower its prices to meet public satisfaction for many years, and several industry analysts have viewed it as abusing its market power by charging consumers high prices that many citizens are unable to afford. The rental charge for an Asymmetrical Digital Subscriber Line (ADSL), for example, comes on top of a phone-line rental, which costs R140 at present (about \$US14) a line. World Wide Worx (2012)'s research on mobile consumers has shown that lower-income South African cellular phone users spend an average total of R100 (about \$US10) per month on their phones. The mere rental component of a line is beyond the reach of most South Africans, let alone the cost of using it to make calls or add ADSL (Goldstuck, 2012). The communications regulator, the Independent Communications Authority of South Africa (ICASA) has been reducing prices in the past couple of years as a result of public demands for affordable communications services. In January 2014, ICASA lowered termination rates again in a quest to lower prices. Although that reduction of prices will decline gradually over three years, there was a sense of relief from consumers as they would pay lower prices in the long run (Mochiko, 2014). This tariff reduction decision by ICASA translates to that the termination rates will fall by 50 per cent by March 2014 to 20 cents a minute and these are fees that mobile operators pay to carry each other's calls. Additionally in 2015, these rates will fall to 15 cents a minute and in 2016 the rates will fall to 10 cents a minute; while the asymmetric termination rate will be 42 cents in 2015, 40 cents in 2016 and 20 cents in 2017. Communications Ministers Yunus Carrim (Mochiko, 2014) urged the mobile operators, especially the dominant Vodacom and Mobile Telephone Networks (MTN), to accept the changes as that would ensure that consumers pay affordable telecommunications prices in order to communicate better. Tariff reduction by ICASA in the past couple of years is commendable as the agency has turned into a new leaf and started getting tougher on service operators by enforcing price reductions. It has taken ICASA years to exercise their power as for many years in the 1990s and the 2000s, this regulator failed to reduce the high tariffs but since 2011 that is no longer the case. The reason for a tougher ICASA could be improved human resources and financial capacity.

Statistics South Africa, in its Consumer Survey of 2007, reported an increase in the ownership of radios, televisions, computers, and mobile phones between 2001 and 2007, but reported a decrease in landline penetration from 24.4 per cent to 18.6 per cent (South African Yearbook, 2008/09, 103). This landline percentage has been slowly declining annually, while mobile phone uptake has been dramatic and significant. The United Nations' e-Readiness Index (2009) indicated that the South African main telephone line index is low, compared to that of other developing countries, and this low fixed-line telephone index raises questions about the e-readiness and the status of South Africa as an information society. South Africa also "suffers from low government ICT adoption, particularly those means of ensuring that we can make government services available online, and the country remains behind in government ICT adoption, compared to countries such as Singapore, Eretria, Finland and others" (Morokolo, 2011a). Wider ICT access and use is necessary in South Africa to ensure wider universal ICT access to ensure that most citizens enjoy social services that allow people to operate in an information society. National ICT indicated that in 2011 not many citizens have access to these technologies, as Figure 1 reflects those data.

Figure 1: Percentage of households with household goods in working order, Census 2001, Community Survey 2007, and Census 2011

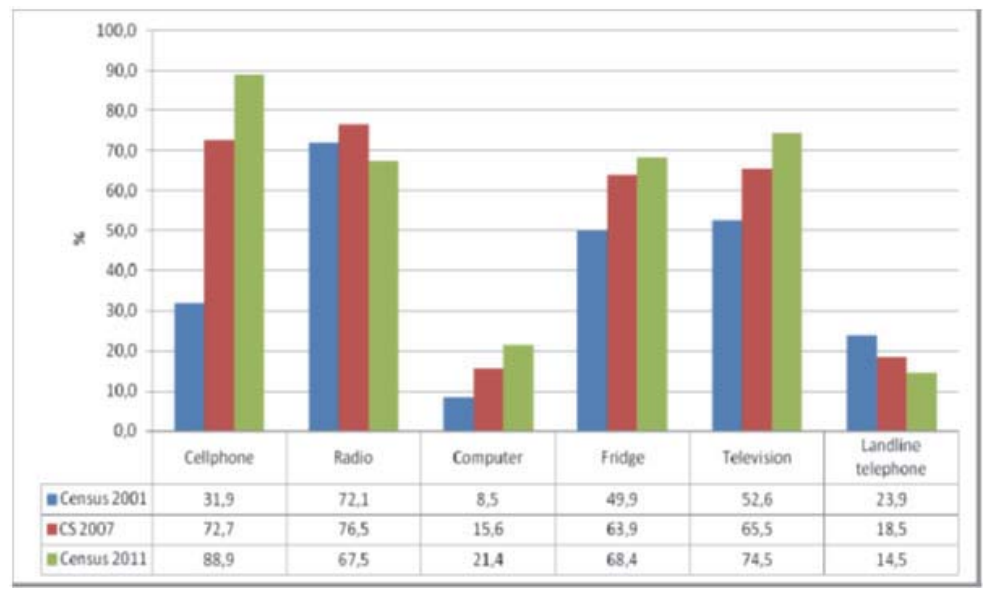

Source: Statistics South Africa Census (2011) 


\subsubsection{Mobile cellular penetration}

As alluded to in the last sub-section, South Africa has witnessed tremendous growth in mobile phone penetration over the past few years. South Africa has five mobile phone operators: Vodacom, Mobile Telephone Networks (MTN), Cell C, Virgin Mobile, and 8ta (or Heita). As in other African countries, mobile phone penetration has surged to greater levels. A South African Communications Minister called the growth "a mobile miracle" (Pule, 2010). Pule also declared that mobile cellular subscriptions in South Africa "were over 50 million in 2010" (e-Skills Institute Newsletter, 2012, 1). Around 10 million phones are sold annually in South Africa, according to Goldstuck (2012), and that smartphones accounted for five (5) million by 2013. Furthermore, an internet report, by World Wide Worx (2012) revealed that cellular phone banking services increased by 37 per cent, and that South Africans in urban and rural areas aged 16 and above use mobile phone banking services for personal and business use. The four biggest mobile phone markets in Africa are Nigeria, South Africa, Kenya, and Ghana (e-Skills Institute Newsletter, 2012a, 1).

\subsection{Usage score}

The usage score indicates the number of Internet subscribers per 100 inhabitants (ITU, 2011). Regarding access to ICT in South Africa, it is clear that the future is the mobile phone. The latest Internet access statistics reveal that few households have Internet access. Most citizens access the Internet from mobile phones rather than home computers. Moreover, only 4.8 per cent of households had access to the internet in 2007. At the end of 2011, South Africa had approximately 8.5 million internet users (World Wide Worx, 2012). This figure (i.e. 8.5 million citizens with Internet access) represents a 25 per cent increase over the 2010 figure of 6.8 million, maintaining a high growth rate fuelled by the explosion of smartphones in the market (Goldstuck, 2012). This growth results in internet penetration in South Africa of approximately 17 per cent. Despite rapid growth, this percentage lags significantly behind the largest Internet user bases in Africa, according to Goldstuck (2012). The countries leading the use of the Internet in Africa are Nigeria, with 45 million users, an indication of 29 per cent penetration; Egypt, with 21.6 million users, representing 26 per cent penetration; Morocco with 15.6 million users, an indication of 49 per cent penetration; and Kenya with 10.4 million Internet users, representing 25 per cent penetration. In all these countries, high Internet access results from Internet access and use via mobile phones, not from home computers since most homes have no computers.

Good progress has also been made in bringing internet access to central government, research, and scientific institutions, and to some extent, schools, hospitals, libraries, and e-community centres, at least in major cities such as Cape Town.

Figures from Statistics South Africa (2011) Census Report indicate a minimal increase in the number of households with internet access over the period 2001 to 2011, with 1239187 (35.2 per cent) households having internet access at home while 9364518 (64.8 per cent or 9.4 million households) have no internet access - not at home, at work, via cellular phone or elsewhere (Sowetan, 2012). These figures indicate high digital divide levels that the government has to address because the internet is regarded as one tool that can reduce digital and information poverty prevailing nationally.

There has been considerable growth in the use of mobile phones and in accessing the internet by means of mobile phones. The use of landlines has declined, as stated earlier. The use of home computers has also not improved much. It is apparent from these figures that if South African ICT and other service providers are to offer South African citizens any kind of services, the mobile phone is the best ICT to use for that purpose. The World Wide Worx study (2012) found that while 28 per cent of the urban cellular market use mobile instant messaging (IM), as much as 65 per cent of users have this capacity on their phones, meaning that only 4.5 million out of 10.5 million potential mobile IM users actually use it. According to the study, some reasons why mobile phone owners had internet applications on their phones but did not use them could be the result of ignorance, cost-related concerns, or phone limitations. The research report showed that the use of specific applications, like MXit and Facebook Mobile, far outpace browsing on the phone, even though both are available on almost two-thirds of the phones used by South Africa's urban cellular phone users.

The South African proportion of households with internet access has improved over the past few years, although these levels are still lower than those of other emerging economies, as can be seen in in Figure 2. 
Figure 2: Internet subscribers per 100 people and households with internet access at home, per cent (2007)
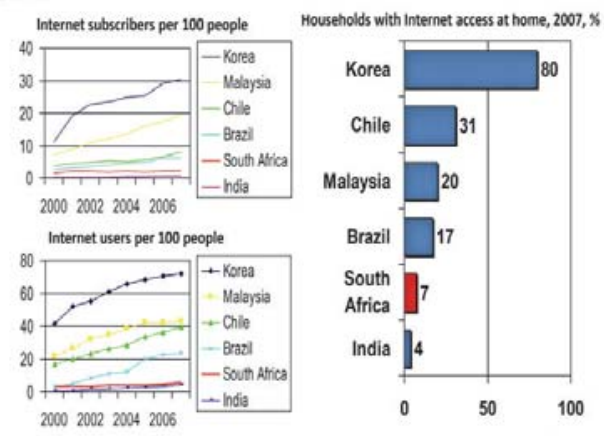

Source: South African Department of Communications (2009) and Sekese (2012)

Figure 2 indicates that South Africa has far fewer internet subscribers, and fewer households with internet access, when compared to the other countries.

\subsubsection{Access to computers}

Few households in South Africa have access to computers. One of the key factors behind the mobile push onto the internet is the low penetration of both computers and fixed-line internet access in South Africa (World Wide Worx, 2012). In Africa, it is estimated that only 7.9 per cent of households have a computer, and half of these are in South Africa and that the total number of computers in use in South Africa, largely in business, is around 9.5 million (Goldstuck, 2012). Statistics South Africa Census (2011) results released by Statistics South Africa in October 2012 revealed that more households have computers compared to ten years ago, with an increase of 21.4 per cent (or 3092542 ), up from 8.5 per cent in 2001 (Sowetan 2012).

Despite these low levels, two-thirds of South African small and medium enterprises (SMEs) declared in the World Wide Worx (2012) internet study that they have Web sites. They are, therefore, reaping the economic rewards derived from internet access and use. This study also indicates that e-commerce is growing at a rate of around 30 per cent per annum and shows no signs of slowing down. What is apparent in this trend is that SMEs benefit more from internet access and use than individuals and households. The result is an internet economy of R59 billion (R representing the Rand which is the South African currency) in 2011, which comprises two (2) per cent of the South African economy, which is expected to grow to 2.5 per cent by 2016 (Goldstuck, 2012). The levels of ICT skills are still low, as briefly assessed in the next sub-section, but are expected to improve in the next few years as a result of training projects currently underway.

\subsubsection{Levels of ICT skills}

South Africa has a shortage of ICT skills, like other sub-Saharan African countries. Because South Africa is the most powerful economy in Africa, it could be expected of South Africa to have ICT personnel with better or advanced ICT skills than other African countries. This, however, is not the case. The government is currently running ICT training programs aimed at alleviating this challenge with the challenge of this ICT skills shortage, starting the establishment of an e-Skills Institute in 2009, which capacitates students with ICT knowledge and skills (e.g., for e-business, e-health and egovernance). An ICT Career Expo, an initiative by the Communications Ministry, in collaboration with the telecommunications services incumbent, Telkom, has also been initiated. Telkom, has injected millions into ICT skills training programs and towards the government's Joint Initiative on Priority Skills Acquisition Initiative while on the other hand charging consumers high telecommunications prices for many years in the past. What is evident is that publicprivate partnership (PPP) attempts in ICT skills development continue to embark on capacity building programs. Furthermore, to improve the national effort to increase the ICT skills-base, the Department of Communications (DoC) continues to partner with universities, Further Education and Training (FET) Colleges, and schools to train citizens in eskills, in cooperation with the e-Skills Institute and its portfolio organizations (Morokolo, 2011b). This ICT skills program forms part of the department's implementation of its 2011-2014 Strategic Plan, which has ICT skills training as one of its main goals. 


\subsection{Quality score}

This score measures the number of international internet bandwidth per 100 inhabitants and also considers broadband speed.

\subsubsection{Broadband Internet penetration}

The 2009 e-Barometer Report revealed that the South African broadband internet penetration growth rates are far lower than that of countries such as Brazil, China, and the Republic of Korea (Bapela, 2011) (reflected in Figure 3).

Figure 3: Range of slowest and fastest broadband speeds available (kpbs)
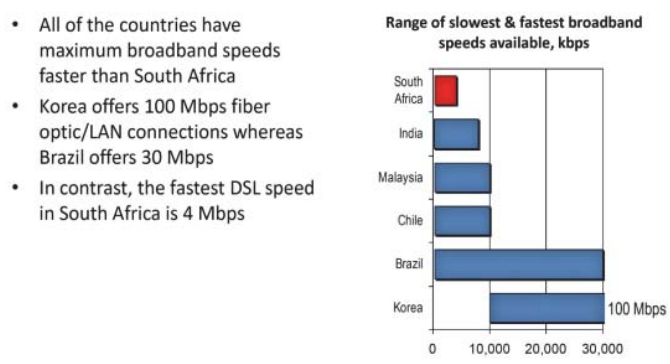

Source: South African Department of Communications (2009) and Sekese (2012)

Information in Figure 3, reveals that the South African internet access levels were low (in 2007) compared to those of the other emerging economies and some BRICS (Brazil, Russia, India and China). India had the smallest number of households with internet access at home (South African Department of Communications, 2009). The Republic of Korea had the fastest maximum broadband speed.

Of the 105 million people using the Internet in Africa in 2011, only 31 million had broadband access, which means that while 12.8 per cent of the population had internet access, only 3.8 per cent had broadband (Goldstuck, 2012). For fixed broadband, the number is lower, with around one million fixed-line broadband subscribers, most of them in South Africa. This is mostly due to low access levels to fixed-line telephones and computers at home (World Wide Worx, 2012). In addition, South Africans' access to radio and television has not reached the required levels, particularly in rural and remote areas. Former South African Communications Minister, Pule (2012), stated that the government remains committed to delivering "100 per cent broadband penetration by 2020 and delivering a million jobs by 2020".

Similar promises of ICT infrastructure delivery by government have been made in the past by other Ministers, but most of these promises have not been fulfilled and the country's ICT infrastructure and services remain poor and unimpressive. It therefore remains to be seen if the current Minister Carrim will differ from his predecessors and convert empty policy promises into reality. At least Carrim delivered a Broadband Policy for public discussion in November 2013 after occupying the ministerial position for merely three months. Critical ICT industry analysts, such as Muller (2012), assess what is needed to deliver ICT infrastructure and services in South Africa as "less talk and trips by government officials and more action." Wireless broadband Internet access remains the strongest growth sector in many countries around the world and this has been the trend as well in South Africa.

\section{Conclusions}

This article explored the progress made by South Africa towards becoming a network and an information society. Current South African ICT statistics were provided and compared to those of other emerging African and BRIC economies. The ICT statistics in this article reveal that most South Africans have access to and use mobile phones, and that access to and use of the other ICT including landlines, computers and the Internet still needs to be improved if South Africa is to be a real information society. National ICT access is prevalent in advanced cyber cities such as Cape Town, but most towns and rural areas, including schools, lack ICT infrastructure and services. Only when the areas lacking ICT have obtained ICT access and use, will South Africa truly be regarded as an information society. South Africa plans to complete its broadcasting digital migration process by 2015. The country, therefore, has one year (2014-2015) to improve public access to broadcasting services and fully digitise broadcasting services. The different economic, political, and social 
revolutions that have transformed South Africa into an industrial society have not changed the country into a digitally networked society. Neither is South Africa producing abundant information as most citizens do not have access to and are unable to afford to afford higher education. Attempts are, therefore, being made to steer the country towards becoming an information society.

To ensure a truly national and inclusive South African information society, much remains to be done to bring its infrastructure and benefits even to the poorest in the country. Future ICT policy directions need to readdress issues, not only of access and of price, but also low quality and slow bandwidth, lack of e-skills and local content and language, and applications targeting users residing in poorer and rural areas. This article is a contribution towards the continuing debates on digital inclusion and universal access to telecommunications services and ICT policy in South Africa. The emergence of mobile devices (such as smart phones and tablet computers) is accelerating this process, but they are still expensive for economically deprived individuals.

\section{References}

Bapela, O. (2011). Speech of the Honourable Deputy Minister of Communications, Mr Obed Bapela, Member of Parliament, on the occasion of the official launch of the e-Barometer Report.

Department of Communications: Republic of South Africa. Retrieved 20 July 2012 fromhttp://www.info.gov.za/speech/DynamicAction? pageid $=461 \&$ sid $=20516 \&$ tid $=38798$

Castells, M. 2000. Materials for an exploratory theory of the network society. British Journal of Sociology 51(1): 5-24. City Press. 2013. Zuma fires ministers Sexwale, Pule and Baloyi. July, 9. www.citypress.co.zal.../zuma-fires-minist...Retrieved on 15-08-2013

Chisango, G. (2013). Technology challenges faced by rural women in the Eastern Cape Province of South Africa: A Chris Hani Municipality Case Study (2012-2013). Pretoria: University of South Africa Master of Arts Thesis.

Fuchs, C., \& Horak, E. (2008). Africa and the digital divide. Telematics and Informatics, 25(2), 99-116.

Goldstuck, A. (2012). Internet Matters: The Quiet Engine of the South Africa Economy. IJohannesburg: World Wide Worx.

Horwitz, R.B., \& Currie, W. (2007). Another instance where privatisation trumped liberalisation: The politics of telecommunications reform in South Africa - a ten year retrospective. Telecommunications Policy, 31(8-9), 445-462.

International Conference on Information and Communication Technologies and Development (ICTD). 2013. What Nelson Mandela said regarding ICT. Cape Town: International Conference on Information and Communication Technologies and Development.

Retrieved from: ictd.cs.uct.ac.za/mandela.html International Telecommunication Union. (2011). Measuring the Information Society. Geneva: International Telecommunication Union.

Kaisara, G., \& Pather, S. (2011). The e-Government evaluation challenge: A South African Batho-Pele-aligned service quality approach. Government Information Quarterly, 28, 211-221.

Lesame, N. C. (2009). The impact of information and communication technologies (ICTs) on development: a case study of the influence of telecentres in the education of users. Pretoria: University of South Africa.

Lyotard, J. F. (1984). The postmodern condition. Manchester: Manchester University Press.

Mandela, N. 1995. Towards a world-wide information society. Intermedia 23(6):46-47.

Matsepe-Casaburri, I. 2005. Budget Speech by the Minister for Communications Dr Ivy Matsepe-Casaburri. Cape Town: South African Parliament. And in South Africa, Department of Communications. (2005). Towards an inclusive information society. Presidential (South African)

National Commission on Information and Development (PNC on ISAD). Pretoria: Government Printers.

Mbatha B \& Lesame, Z. 2014. South Africa Goes Digital: Possible Obstacles to the Adoption of Digital Television. Mediterranean Journal of Social Sciences 5(1): 89-96.

Mbeki, T. M. (2003). State of the Nation Address by the President of South Africa. Cape Town: South African Parliament.

Mda, Z. 2014. It's not over yet. Voices. City Press. February 9: 25.

Mobile Internet booms in South Africa. (2010, May 27). Mail \& Guardian Online Staff Reporter. Retrieved 04 September 2012 from http://mg.co.za/article/2010-05-27-mobile-internet-booms-in-south-africa

Mochiko, T. 2014. Icasa releases final regulations on mobile termination rates. Business Day Live. January 29: 1

Retrieved from www. bdlive.co.za/business/technology

Morokolo, E. (2011a). DOC lays out priorities. SAITNEWS: Tracking IT in the public sector. Retrieved 11 March 2012 from http://saitnews.co.za/e-government/460/

Morokolo, E. (2011b). SA broadband still lags behind. SAITNEWS. Retrieved 11 March 2012 from http://saitnews.co.za/broadband/ broadband/

Muller, R. (2012, May 17). The broadband pipedream. MyBroadband Tech and IT News Online. Retrieved 02 June 2012 from http://mybroadband.co.za/news/broadband/50115-the-broadband-pipe-dream.html

Mungadze, S. 2013. South Africa to finally have broadband policy by November. Business Day Live September 30:1. http://www.bdlive.co.za/business/technology/2013/09/30/south-africa-to-finally-have-...Retrieved on 05/02/2014

Oyedemi, T. D. (2011). Digital inequalities and implications for social inequalities: a study of internet penetration amongst university students in South Africa. Telematics and Informatics, 29, 302 - 313.

Padayachie, R. L. (2010). eBarometer: Measuring the impacts of ICTs on development in South Africa. Pretoria: South African 
Government National Department of Communications.

Perry, S. (2011). Measuring up: the DoC (South African Government National Department of Communications) released its eBarometer Index in early August. Brainstorm Magazine Online. Retrieved from http://www.brainstormmag.co.za/index.php?option=com_ content\&view=article\&id=4 13 October 2013

Pule, D. (2010). "E-Skills Key to our Future:" Opening address by South African Deputy Minister of Communications at the E-Skills Summit. Cape Town: Cape Sun Hotel. July 26-28. SA Unemployment. 2014. www.tradingeconomics.com/southafrica/...Retrieved on 12-02-2014

Sekese, R. (2012). Re-Request for permission to use research results in an academic article. Pretoria: South African Government National Department of Communications.

Songan, P., Harris, R. Bala, P. \& Khoo, G. L. 2000. Awareness and usage of information technology in a rural community of Bario, Sawarak. In M. Leigh (ed). Borneo, 2000. Politics, History and Development. University Malaysia Kota Samarahan, Sawarak, pp. 560-575.

South African Constitution. 1996. Cape Town: South African Parliament and Government Printers.South African Department of Communications. (2005). Towards an inclusive information society. Presidential (South African) National Commission on Information and Development (PNC on ISAD). Pretoria: Government Printers.

South African Department of Communications. (2009). International peer benchmarking study on the South African ICT sector. a study conducted by BMI-TechKnowledge Group for the Department of Communications. Pretoria: Government Printers.

South African Government Communications and Information Services (GCIS). (2009). Yearbook 2008/09. Pretoria: Government Printer.

South African Department of Communications. (2010). South African National e-Skills Plan of Action - NeSPA. Pretoria: Government Printers.

South African Department of Communications. (2012a). Aggregation of e-Skills Effort across South African e-Skills Institute Newsletter, 5:2.

South African e-Skills Institute. (2012b). e-Skills Institute Newsletter. 2, 1-2.

South African e-Skills Institute. (2013). 2013 - The year of collaboration, connectedness and creating positive change in the development of the people of South Africa. Edition 21: 1.

South African Department of Communications. (2012b). Local evidence-based research into mobile needs in South Africa. e-Skills Institute Newsletter, 6:1.

South African National Planning Commission. (2011). Diagnostic Overview: South Africa. Pretoria: Union Buildings. Retrieved online at: http://www.gov.za/documents/download.php\%3Ff\%3D147192 Accessed on 20-03-2013

South African Network Survey. 2013. City Press May 19: 8.Sowetan Newspaper. 2012. Census 2011: It's looking up for SA. October 31:12.

South African Telecommunications Act No. 103. 1996. Pretoria: Government Printers.Statistics South Africa Census. (2011). Pretoria: Statistics South Africa.

Sowetan Newspaper. (2012). Census 2011: It's looking up for SA. October 31:12.

Sussman, G. (1999). The information society: discourse, fetish and discontents. Journal of International Communication, 6(1), 7-22.

Wesso, HM. (2010). Address by Acting Director-General at the opening of the Research Network (ResNes) Research Colloquium. Cape Town: Cape Sun Hotel. July 26-28.

World Summit on the Information Society Declaration of Principles. (2005). South African Presidential National Commission on Information and Development (PNC on ISAD): Towards an inclusive Information Society. Pretoria: South African Government National Department of Communications.

World Wide Worx. (2012). Internet matters: the quiet engine of the South Africa economy: internet access in South Africa. Johannesburg: World Wide Worx. Retrieved 21 September 2012 from www.internetmatters.co.za 